\title{
Research on Cultivating Linguistic Skills of Cross-border E-commerce English Talents under the Background of "One Belt and One Road"
}

\author{
Guojian Zhang \\ Xi'an FanYi University, Xi'an Shaanxi, 710105, China
}

Keywords: Cross-border E-commerce, English Talents, Cultivation of Skills.

\begin{abstract}
During recent years, with the declining quantity of traditional trades and implementation of Chinese "One Belt and One Road" development strategy, cross-border e-commerce has developed rapidly as an important way for foreign trade enterprises to implement transformation and upgrading. Meanwhile, it has resulted in the problem of scare corresponding talents. Thus English linguistic skill has become the necessary skill of such talents. In this paper, by taking Xi'an as an example, it has emphasized on studying the problem of cultivating the English skills of cross-border e-commerce talents.
\end{abstract}

\section{Introduction}

In 2013, China put forward the development strategy of "One Belt and One Road", which put forward a new subject for Chinese foreign trade enterprises. Meanwhile, confronted by the recession of global trade and the arrival of "Internet +" Era, a lot of Chinese enterprises and individuals have successively tried the new foreign trade of cross-border e-commerce, so as to promote the transformation and upgrading of enterprises. Under the background, the large insufficiency of English talents proficient in cross-border e-commerce skills has been increasingly highlighted. Therefore, targeted at the cross-border e-commerce enterprises in Xi'an, members of this subject have developed the researches on cultivating the English linguistic skills of related talents, with the hope of offering beneficial references for organizations of talents cultivation.

\section{Part One English Language Skills of Commerce Talents under the Background of "One Belt and One Road"}

During recent years, due to huge "gravitational wave" caused by strategic implementation and rapidly developed cross-border e-commerce "New Engine", it has produced a lot of demands for talents. Of which, requirement of English talents is mainly embodied in the linguistic skills of commerce operation. According to the business order, it is mainly divided into the following aspects:

Construction of Website Content.

English language skills involved in the construction of website content mainly include translation of products introduction and contents of all website sections, namely the ability to describe the transaction products and website contents in English based on the e-commerce environment.

Promotion of Commerce Website.

Smooth development of cross-border e-commerce needs to do a certain overseas promotion job of the commerce website, which involves in quite good English language skills. Generally speaking, enterprises' marketing stuff or PR need to possess such a linguistic skill.

\section{Online Marketing.}

Online marketing is the most core business link of cross-border e-commerce activities, which is equivalent to the trade negotiation link in traditional international trade. Of which, English language skills involve in the following business procedure:

a). By taking advantage of SE, all kinds of websites and e-commerce integrated software, it develops online marketing, such as investigating products and individual data of consumers online, personalized ads push, publishing information of enterprises and products, so as to increase the SE flow. 
b). Online customer development and after-sales service, such as looking for and analyzing potential foreign customers online, writing sales promotion letter and product catalog or instruction, developing differential service, coping with customer feedback and complaints.

c). Negotiating transaction conditions online, such as inquiry, offer, counter offer, placing orders, answering orders, request for changing orders, electronic signature, which are manly completed by foreign business correspondence(email). It is the commercial activity link requiring most linguistic skills and highest requirements, such as the written communication skills in English based on the e-commerce environment, including English reading, writing and translation abilities. This link requires the staff (buyer and seller) to be familiar with common online communication languages in the e-commerce, master the international trade terms and business negotiation skills. According to the type of commercial activities(generally divided into B2B, B2CM C2C and $\mathrm{O} 2 \mathrm{O}$ ), people should correctly apply the online communication strategies and skills in different trade stages, so as to realize the online negotiation online and finally make the deal. For instance, when the seller responds to the inquiry of buyer online, the language should be simple and understandable, the expression should be sufficiently accurate in normal form and the seller should master the responding time and frequency.

d). Handling the fulfillment business online, such as payment, transportation, insurance, customs inspection and clearance, including filling, inspection and amendment of a series of trade documents,

In addition, online technology and commercial comprehensive management level also involve in English language skills.

\section{Current Situations of Cross-border E-commerce Talents' English Language Skills in Xi'an}

Since there are so many requirements of English language skills, how should cross-border e-commerce talents in Xi'an improve their English language skills? Next, it will be summarized from three aspects: enterprise, universities and colleges, social training organizations.

\section{Current Situations of English Skills of Employers in Cross-border E-commerce Enterprises.}

By visiting and investigating related enterprises, the author has discovered the following problems:

There is a certain "fraction" between linguistic skills of cross-border e-commerce practitioner's English certificate and the skill required by actual e-commerce work, which is mainly embodied as: the accuracy or fluency of English expression is not high, there are problems which can be avoided or corrected, such as wrong English expression and slow replying speed online.

Workers of cross-border e-commerce enterprises rely on the translation software excessively. Due to poor English foundation or greedy for simplifying matters and communicating efficiency, they cannot or do not recognize or correct errors appearing in the translation software, who result in un-smooth translation of product information and low quality of online communication.

Current Situations of Cultivating Cross-border E-commerce Talents' English Language Skills in Related Majors of Universities and Colleges.

Currently, English skills of graduates majored in related departments of universities and colleges in Xi'an still cannot completely achieve the requirements of cross-border e-commerce enterprises, the main reasons are as follows:

Universities or colleges do not specifically set up cross-border e-commerce major or course, which just join in that simply and do not realize the high integration of English and cross-border e-commerce. Moreover, there are few lessons. Students are lack of related practical teaching or practical quality training.

Universities or colleges are lack of cooperation with cross-border e-commerce enterprises. Teaching contents are disconnected with the practical business.

Universities and colleges are lack of cross-border e-commerce teaching materials. Teaching contents give priorities to theory than practice.

The teaching staff is lack of composite academic background of English and e-commerce. 


\section{Current Situations of Cross-border E-commerce English Talents' Skills Cultivated in Social Training Organizations}

Currently, there are few social organizations engaged in training cross-border e-commerce English talents in Xi'an. Besides, most social organizations have the disadvantages: short training period, less practical training and taking the passing rate of certificate as the major objective and evaluation method. Therefore, talents cultivated by those organizations cannot completely satisfy the requirements of enterprises.

To a certain extent, the above situations have restricted the healthy and rapid development of cross-border e-commerce in Xi'an.

\section{Explorations of Xi'an's Mode of Cultivating Linguistic Skills of Cross-border E-commerce English Talents}

As is known to all, talents cultivation is a systematical engineering, which needs positive cooperation and all-round investments of all parties. It cannot be separated from the universities or colleges as the source of cultivation or social training organizations, or be separated from the closed-loop enterprises, or related governmental departments in charge of the talents cultivation. Next, the author will explore the four aspects involved in talents cultivation.

\section{Sufficient Guarantee of Governmental Departments.}

As the supervising organizations, governments have played the roles of top planning, political guidance, system supervision and supporting guarantee. Nowadays, under the general background of economic transformation, upgrading and development and fighting for world-class advanced education, it seems more important for governmental education authorities to guide, supervise and serve the cultivation of talents. In view of the analysis on the talents demand and current situations as mentioned above, the author considers that local governments should reinforce the following work:

a). By scientifically developing Xi'an's long-term plan in developing and cultivating talents for cross-border e-commerce enterprises, it can vigorously guarantee the supply of e-commerce talents. According to national and regional development plans and international market trends, relevant governmental departments can formulate the concrete long-term plan of cross-border e-commerce English talents, according to the practical situations of cross-border e-commerce industries(such as fruit, plant extraction, mechanical apparatus, glass ware) and universities and colleges, and also specify tasks for relevant universities and colleges, further to implement the responsibility of talents cultivation. For instance, Xi'an Fanyi University can be designated to undertake the cultivation of cross-border English talents for some industries.

b). It should continue to play the role of political orientation and systematical supervision, vigorously guide and standardize relevant colleges and universities to develop into the application-oriented ones, further to cultivate more professional talents and solve the "two difficulties": it is hard for enterprises to recruit people and students to find jobs. Consequently, relevant governmental departments can try the following ways:

First of all, by giving full play to the integrated resources, it can set up the educational mechanism jointly implemented by the government, enterprise, industry and college. The government can take the lead to set up the organization of "cross-border e-commerce educational association", so as to open the "vertical channel" of talents cultivation. Four parties should jointly participate in the whole process of talents cultivation, further to guarantee the English teaching contents to be seamlessly connected with the talents need of e-commerce enterprises. Meanwhile, it should promote the enterprises-universities-researches integration.

Secondly, by giving play to the system supervision, the government should formulate the "Standard for Practicing English Skills of Cross-border E-commerce Talents", so as to regulate universities and colleges and social training organizations to cultivate talents.

c). By positively giving play to the service guarantee, the government should set up "Cross-border E-commerce Affairs Office", so as to offer services and guarantees for the cultivation 
of cross-border e-commerce talents, including organization management, information sharing, personnel training, certificate of ability and supporting capital. For instance, it can hold the public lecture of cross-border e-commerce English talents, English Skills Competition and seminar of English talents cultivation in e-commerce enterprises throughout the province.

\section{Scientific and Standard Cultivation in Universities and Colleges.}

As the major channel of talents cultivation, universities and colleges should be scientific and standard while cultivating the cross-border e-commerce English talents. Thus they can make efforts from the following aspects:

a). By taking the talent demand of e-commerce markets both at home and abroad as the orientation, it should scientifically develop the program of cultivating cross-border e-commerce talents. According to the latest trends in the industry, it should adjust the settings of relevant English courses, so as to realize the seamless joint between teaching content and industrial practice. For instance, universities and colleges can integrate relevant courses of different majors, set up courses of cross-border e-commerce business English and online marketing English, increase the fitting degree of English teaching contents and e-commerce business, and also realize the high integration of English and business courses.

b). It should select the latest application-oriented teaching materials and organize backbone teachers of universities and colleges and experts of enterprises to jointly compose teaching materials or formulate handouts, so as to guarantee the latest practical language knowledge and skills to enter the classroom.

c). It should vigorously promote the exploration of talents cultivation mode. Cross-border e-commerce English talents belong to application-oriented talents, thus it should adopt the cultivation mode with strong practical nature. For instance, universities and colleges can set up the "Cross-border E-commerce Order Class" with the governments, industries and enterprises, or construct the talents cultivation demonstration base and innovation incubation park jointly; and also carry out practical operation by registering enterprises or online stores on the cross-border e-commerce platform by taking class as the unit, thus students can learn linguistic skills in practical business operation. By taking advantages of governmental supporting policies, it can set up enterprises offering the service of cross-border e-commerce and let students undertake the outsourcing businesses. All these belong to the objective teaching mode integrating teaching with enterprises, which enable students to master the cross-border e-commerce English skills in "practice".

d). It should positively develop the reform of teaching methods. Teachers can try the following teaching methods.

1). By taking advantage of information offered on the cross-border e-commerce platform, teachers can look for English terms and sentence patterns as the teaching materials, which are most suitable for the theme of every class, or cooperate with workers of cross-border e-commerce platform and formulate the English teaching materials.

2). According to concrete procedures of cross-border e-commerce platform, including the platform construction, looking for customers, product promotion, business negotiation, order processing, payment, packaging and transportation and after-sales service, teachers can train students' English skills, such as looking for latest information and client's information on international English websites, describing the products in English, communicating with foreign customers in English, handling all kinds of English documents and offering voice service in English.

3). It should vigorously develop practical teaching of cross-border e-commerce business, including organizing students to practice in enterprises, cooperating and developing simulation operation platform with cross-border e-commerce, regularly holding cross-border business competition, encouraging students to open their own online stores on the mainstream cross-border e-commerce platforms, implanting practice of enterprises' projects, so as to let students exercise their English skills required by cross-border e-commerce in practice.

4). By taking advantage of QQ and WeChat, teachers can upload relevant cross-border e-commerce English as teaching contents, so as to implement flipped classroom and project teaching. 
5). By setting up online communication language templates, teachers can classify and summarize common English in different business stages.

e). It should vigorously cultivate English skills of relevant teachers, develop cultivation of trans-disciplinary teaching stuff, or dispatch teachers to take further study or take a temporary post in cross-border e-commerce enterprises.

Cultivation by Seeking Help from Social Training Organizations.

Social training organizations can cultivate talents fast and smoothly within a short time. Besides, they take the passing rate of certificate examination as the evaluation standard, thus students are lack of actual professional abilities. Consequently, the government can have a try as follows:

a). On the basis of standard management, the government can offer certain subsidiaries to social training organizations together with cross-border e-commerce enterprises.

b). It can select some employees of cross-border e-commerce enterprises and university teachers to focus on training graduates with certain English and computer foundation, and then allocate those students to cross-border e-commerce enterprises.

c). Employment rate of learners and employment satisfaction degree of enterprise should be considered as the hard indicator to evaluate the social training organizations.

\section{Joint Cultivation of Enterprises and Universities and Colleges.}

As the parties using talents, cross-border e-commerce enterprises should develop close cooperation with Foreign Language Department of universities and colleges, give feedback of new and old workers' English skills in time, and also regularly hold classes for improving English skills, E-commerce English salon and Linguistic Skill Competition; and also contact with excellent students majored in English of universities and colleges, make communications in time in various forms and make up for their respective short boards quickly.

As a conclusion, cultivation of cross-border e-commerce talents' English skills needs the coordination and operation of government, enterprise, society and universities and colleges. To set up a comprehensively three-dimensional cultivation mode, it can satisfy the demands of cross-border e-commerce rapidly developing in Xi'an.

\section{Acknowledgments}

This paper is the research result of social science planning subject of Xi' an, Serial No. 15XF04.

\section{References}

[1] Fan Xinmin. Internationalization of Advanced Education and Cultivation of Cross-border Foreign Trade E-commerce Talents: Cross-border Integrated Perspective, Journal of Hebei Normal University (Educational Science). 2015,(3): 101-107.

[2] Wang Jin. Strategies for Cultivating Core abilities of Cross-border E-commerce Talents under the Background of Industrial Upgrading, Contemporary Vocational Education. 2015,(9): 37-39.

[3] Yang Linlin. Constructing Synergistic Educational Mode of Cross-border E-commerce Platform Relying on Regional Economic Development--Taking Commerce English as an example, Journal of Hubei University of Economics(Humanities and Social Sciences Edition), 2015,(4): 189-191.

[4] Zhuang Xiaolan. Analysis on Core Skills Required by Cross-border E-commerce Talents and Cultivation Countermeasures, Management and Observation,2015, (17): 178-180.

[5] Mei Jiangqiao. Researches on the Characteristics of Demands for Cross-border E-commerce Talents, Management and Observation, 2014, (31): 119-120. 